\title{
WACANA MENGHIDUPKAN KEMBALI GBHN \\ DALAM SISTEM PRESIDENSIL INDONESIA
}

(The Discourses Revive the DPSP in the Presidential System of Indonesia)

\author{
Mei Susanto \\ Dosen pada Departemen Hukum Tata Negara \\ Fakultas Hukum Universitas Padjadjaran \\ Jalan Dipati Ukur No. 35 Bandung, 40132,
}

Telepon 022-2503271, Fax 022-2533705, Email.m.susanto@unpad.ac.id

Tulisan Diterima: 11-05-2017; Direvisi: 05-08-2017; Disetujui Diterbitkan: 22-08-2017

\begin{abstract}
This research examine the discourse of reviving the Directive Principle of State Policies (DPSP) as a national development planning guideline that is often contrary with a presidential system. The problem research, first what is the legal form of DPSP that does not conflict with the presidential system? Second, what are the legal implications of DPSP violations by the President according the presidential system? By using normative legal research methods, this research concluded that DPSP is not always in conflict with presidential system by placing it in the constitution. The legal form DPSP in the constitution makes national development planning not only the preident domain, but result of mutual agreement in accordance with the social basis of the pluralistic Indonesian society. The DPSP violations cannot have implications for dismissal of the President, because DPSP is still a morally binding guide. The legal system for evaluating DPSP violations can be through the MPR by ordering the House of Representatives to effectively use parliamentary budgetary rights or the Constitutional Court with judicial review or constitutional complaint. The Revive of DPSP can be done by amendment the 1945 Constitution by the MPR.
\end{abstract}

Keywords: Constitution, Directive Principle of State Policies, Presidential System.

\begin{abstract}
ABSTRAK
Penelitian ini membahas wacana menghidupkan kembali GBHN sebagai pedoman perencanaan pembangunan nasional yang sering dibenturkan dengan sistem presidensil. Permasalahan yang diteliti, pertama bagaimana bentuk hukum GBHN yang tidak bertentangan dengan sistem presidensil? Kedua, bagaimana implikasi hukum pelanggaran GBHN oleh Presiden sesuai sistem presidensil? Dengan menggunakan metode penelitian hukum normatif, penelitian ini memperoleh kesimpulan GBHN tidak selalu bertentangan dengan sistem presidensil dengan cara menempatkannya dalam konstitusi. Bentuk hukum GBHN dalam konstitusi membuat perencanaan pembangunan nasional tidak menjadi domain presiden saja tetapi hasil kesepakatan bersama sesuai dengan basis sosial masyarakat Indonesia yang majemuk. Pelanggaran GBHN tidak dapat berimplikasi pada pemberhentian Presiden, karena GBHN masih bersifat panduan yang mengikat secara moral. Pranata hukum untuk mengevaluasi pelanggaran GBHN, dapat melalui MPR dengan memerintahkan DPR untuk menggunakan hak budget parlemen secara efektif atau Mahkamah Konstitusi melalui judicial review ataupun constitutional complaint. Penghidupan GBHN ini dapat dilakukan dengan melakukan perubahan UUD NRI Tahun 1945 oleh MPR.

Kata Kunci: Konstitusi, GBHN, Sistem Presidensil.
\end{abstract}




\section{PENDAHULUAN}

Garis-Garis Besar Haluan Negara (GBHN) menjadi salah satu isu sentral yang menjadi perbincangan ketatanegaraan pada saat ini. Dalam berbagai kesempatan sosialisasi empat pilar bernegara oleh Majelis Permusyawaratan Rakyat (MPR), wacana menghidupkan kembali GBHN sebagai pedoman perencanaan pembangunan nasional menjadi salah satu materinya. Hal tersebut tidak terlepas dari Rekomendasi Nomor 2 Keputusan MPR RI Nomor 4/MPR/2014 tentang Rekomendasi MPR RI Masa Jabatan 2009-2014, yang menyebutkan "Melakukan reformulasi sistem perencanaan pembangunan nasional dengan model GBHN sebagai haluan penyelenggaraan negara" (Sadono, 2016: 2). Inilah cikal bakal "formal" merebaknya isu menghidupkan kembali GBHN , dimana dalam Undang-Undang Dasar Negara Republik Indonesia (UUD NRI) Tahun 1945 Sebelum Perubahan (asli) menjadi salah satu kewenangan MPR (Pasal 3) namun setelah dilakukannya Perubahan UUD NRI Tahun 1945, kewenangan tersebut dihapuskan.

Wacana tersebut seolah memperoleh "gaungnya", setelah Presiden ke-5 RI sekaligus Ketua Umum PDI-P Megawati Soekarnoputri dalam Rapat Kerja Nasional PDI-P,pada 10-12 Januari 2016 di Jakarta menyampaikan pidato yang menyindir model perencanaan pembangunan saat ini yang diibaratkannya seperti poco-poco (http://nasional.kompas.com/read/2016/ 01/10/16053561/Kritik.Demokrasi.Indon esia.Megawati.Sebut.seperti.Pocopoco, diakses 24 Mei 2016). Kondisi demikian diakibatkan model kepemimpinan negara Indonesia yang saat ini menggunakan sistem presidensil, dimana Presiden dan Wakil Presiden dipilih secara langsung oleh rakyat dalam pemilihan umum, membuat Presiden dan Wakil Presiden terpilih sibuk menerjemahkan visi-misi dan janji politik yang dibuatnya ketika pemilihan umum, tanpa kemudian memperhatikan pembangunan yang berkelanjutan. Menurut Mega, gagasan pemilihan langsung ditelurkan untuk mendekatkan rakyat kepada calon pemimpinnya itu adalah suatu hal yang positif dalam demokrasi. Namun, ketika terjadi pergantian pemimpin, berganti pula kebijakan yang dilahirkan di dalam pembangunan. Inilah kelemahan yang mengancam pembangunan nasional yang berkelanjutan. Atas kritik tersebut, disarankanlah wacana menghidupkan kembali Pembangunan Nasional Semesta Berencana yang dulu pernah ada ketika Orde Lama, ataupun Garis-Garis Besar Haluan Negara (GBHN) yang pernah ada ketika Orde Baru.

Silang pendapatpun muncul terhadap kritik Megawati tersebut. Namun, sebagai pemimpin the ruling party saat ini, ide tersebut memperoleh sambutan yang cukup luas dari berbagai elemen masyarakat, khususnya lembaga-lembaga negara. Salah satu tanggapan yang menarik ditulis Yudi Latif dalam Harian Kompas 12 Februari 2016 berjudul Basis Sosial GBHN. Dalam tulisannya, Yudi Latif menggunakan pendekatan demokrasi mayotarian vs demokrasi konsensus dari pemikir kenamaan Arend Lijphart. Melalui pendekatan tersebut, demokrasi mayotarian tidak compatible untuk Indonesia karena akan mengancam kelompok minoritas. Demokrasi mayotarian hanya cocok jika pemerintahan dapat dimenangkan secara bergantian baik pihak mayoritas dan minoritas, yang itu hanya mungkin terjadi dinegara yang menganut sistem dwi partai seperti Amerika, Inggris, Selandia Baru dan Barbados. Selain itu demokrasi mayotarian juga cocok bagi negara yang masyarakatnya homogen. Dua kondisi tersebut tidak ada di Indonesia, sehingga model demokrasi mayotarian dianggap tidak akan cocok untuk diberlakukan di Indonesia (Yudi Latif, Basis Sosial GBHN, Harian Kompas 12 Februari 


\section{6. http://print.kompas.com/baca/ 2016/02/12/Basis-Sosial-GBHN, diakses 24 Mei 2016).}

Karena itu, Yudi Latif menyanjung para founding fathers Indonesia yang menyusun pemerintahan Indonesia dengan demokrasi permusyawaratan yang menekankan daya-daya konsensus (mufakat) di bawah sistematik negara kekeluargaan. Demokrasi permusyawaratan ini berusaha mengatasi paham perseorangan dan golongan. Yang dihindari bukan saja dikte-dikte diktator mayoritas, melainkan juga dikte-dikte tirani minoritas dari oligarki elite penguasa dan pengusaha. Dalam ungkapan Soekarno, demokrasi kita janganlah mengikuti model "mayorokrasi" dan "minorokrasi".

Dalam konteks negara kekeluargaan dengan demokrasi konsensus ala Indonesia, kebijakan dasar (rencana) pembangunan tidaklah diserahkan kepada Presiden sebagai ekspresi kekuatan majoritarian. Kebijakan dasar rencana pembangunan harus dirumuskan bersama melalui mekanisme konsensus seluruh representasi kekuatan politik rakyat dalam suatu lembaga perwakilan terlengkap. Karena itu, para founding fathers merumuskan UUD 1945 dengan menempatkan MPR sebagai lembaga perwakilan terlengkap karena di dalamnya terdapat unsur DPR, utusan golongan dan utusan daerah, yang masing-masing unsur mencerminkan keterwakilan politik, fungsional dan teritorial, sehingga seluruh elemen masyarakat hendak dirangkul dan diberikan tempatnya di lembaga perwakilan (Asshiddiqie, 2008: 153). Dengan demikian MPR diberikan kewenangan membuat GBHN sebagai pedoman pembangunan nasional yang berkelanjutan sebagaimana terdapat dalam Pasal 3 UUD 1945 Sebelum Perubahan, "Majelis Permusyawaratan Rakyat menetapkan Undang-Undang Dasar dan garis-garis besar daripada haluan negara."

Permasalahannya, setelah reformasi khususnya melalui Perubahan UUD 1945, lembaga perwakilan terlengkap yakni MPR sudah berganti model perwakilannya dengan kewenangan yang juga kurang memadai. MPR terdiri dari anggota DPR dan anggota DPD, yang menunjukkan hanya merepresentasikan perwakilan politik dan perwakilan daerah, sementara perwakilan fungsional ditiadakan (Manan, 2003: 72). Sementara itu kewenangan yang bersifat strategis hanya mengubah UUD dan memberhentikan Presiden dan/atau Wakil Presiden dalam proses impeachment. Dua kewenangan tersebut bersifat tidak pasti dan harus menunggu momentum perubahan undang-undang dasar dan penjatuhan Presiden dan/atau Wakil Presiden. Selain itu, MPR hanya diberikan kewenangan yang sifatnya seremonial berkaitan dengan pelantikan Presiden dan/atau Wakil Presiden. Dengan demikian, terdapat kesenjangan antara kondisi ideal yang dicita-citakan dalam konsep negara kekeluargaan dengan ketentuan dalam Perubahan UUD NRI Tahun 1945 khususnya berkaitan dengan kelembagaan MPR termasuk dalam pengimplementasian kewenangan MPR yang terbatas tersebut.

Dihapuskannya kewenangan MPR untuk membuat GBHN sendiri sejalan dengan perubahan sistem hubungan antara MPR dengan Presiden, dimana Presiden dipilih langsung oleh rakyat (direct popular vote), yang meniadakan hubungan tanggungjawab Presiden kepada MPR, sehingga GBHN sebagai instrumen pengukur pertanggungjawaban Presiden tidak diperlukan lagi (Manan, 2003: 7980). Sebelum Perubahan UUD NRI Tahun 1945, kewenangan MPR membuat GBHN yang diformalkan dalam bentuk hukum Ketetapan (TAP) MPR, yang ditempatkan sebagai peraturan perundang-undangan tingkat tinggi di bawah UUD 1945 dan di atas UU, yang sejalan dengan kewenangan MPR memilih Presiden dan Wakil Presiden serta menetapkan GBHN dalam peraturan perundang-undangan tingkat tinggi. Oleh karena itu pelanggaran terhadap GBHN pun akan memberikan 
konsekuensi permintaan pertanggungjawaban dari MPR kepada Presiden dan Wakil Presiden.

Karena Perubahan UUD 1945 dengan semangat memperkuat sistem presidensil dengan salah satu bentuknya Presiden dipilih langsung oleh rakyat, maka penghapusan kewenangan MPR membuat GBHN menurut Saldi Isra adalah suatu hal yang logis. Apalagi MPR bukan lagi sebagai lembaga tertinggi dan tidak memiliki kewenangan memilih dan mengangkat Presiden dan Wakil Presiden, yang berakibat pada pertanggungjawaban pelaksanaan GBHN oleh Presiden dan Wakil Presiden kepada MPR (Isra,http://nasional.kompas.com/read/2 016/01/12/15320071/Wacana.Menghidu pkan.GBHN?page $=$ all, diakses 6 Juni 2016). Menurut Saldi Isra, wacana menghidupkan kembali GBHN patut ditolak karena tidak sesuai lagi dengan bangunan sistem pemerintahan presidensil yang telah disepakati dipertahankan saat perubahan UUD 1945. Karena membayangkan GBHN dibuat MPR tentu saja menempatkan kembali MPR sebagai lembaga tertinggi negara. Dalam posisi ini, GBHN yang dibuat MPR tentu saja akan menghadirkan pola sistem pertanggungjawaban Presiden kepada MPR (Isra, 2016: 14). Kalau hendak mengembalikan pola lama, jalan yang harus ditempuh kembali secara utuh pada pola hubungan antar lembaga sebelum perubahan UUD 1945 atau campakkan sistem presidensil.

Kedua pendapat pakar tersebut, baik itu Yudi Latif dan Saldi Isra memiliki basis teoritis yang dapat dibenarkan. Tetapi muncul pertanyaan adalah, apakah dua pendapat tersebut tidak dapat disandingkan dan tidak dapat saling melengkapi? Apakah perencanaan pembangunan model GBHN akan selalu bertabrakan dengan sistem presidensil?

Berdasarkan hal tersebut, tulisan ini hendak membedah permasalahan menghidupkan kembali GBHN yang dikaitkan dengan sistem pemerintahan presidensil secara lebih komprehensif. Terutama bentuk hukum GBHN dan implikasi pelanggaran yang mungkin terjadi. Dengan demikian diharapkan diperoleh gambaran kemungkinan adanya pembangunan model GBHN yang sejalan dengan sistem presidensil.

Adapun rumusan masalah yang hendak diteliti dalam tulisan ini adalah bagaimana bentuk hukum GBHN yang tidak bertentangan dengan sistem pemerintahan presidensil? Dan bagaimana implikasi hukum pelanggaran GBHN oleh Presiden agar tidak merusak bangunan sistem pemerintahan presidensil yang dianut?

\section{METODE PENELITIAN}

Penelitian ini merupakan penelitian hukum (legal research), yang menurut F. Sugeng Istanto adalah penelitian yang diterapkan atau diberlakukan khusus pada ilmu hukum (Istanto, 2007: 29). Morris L. Cohen mengatakan legal research is the process of finding the law that governs activities in human society (Dalam Marzuki, 2005: 29). Lebih spesifik penelitian ini merupakan penelitian hukum normatif yang meneliti azas hukum, sistematika hukum, taraf sinkronisasi hukum, sejarah hukum dan perbandingan hukum (Soekanto, 2007: 51). Berdasarkan hal tersebut, permasalahan GBHN dikaitkan dengan sistem pemerintahan presidensil, diteliti dengan menggunakan penelitian hukum untuk mendapatkan deskripsi mengenai hukum yang menyangkut aktivitas pemerintahan dalam menyusun perencanaan pembangunan GBHN yang sejalan dengan sistem pemerintahan presidensil tersebut. Juga dilakukan pengkajian aturan-aturan yang diterapkan dalam pelaksanaan model perencanaan pembangunan Indonesia yang saat ini menggunakan Sistem Perencanaan Pembangunan Nasional (SPPN), Rencana Pembangunan Jangka Panjang Nasional (RPJPN), Rencana Pembangunan Jangka Menengah Nasional (RPJMN) serta 
mempelajari juga model GBHN yang pernah berlaku di Indonesia.

Merujuk pada pendekatan dalam penelitian hukum, penulis menggunakan pendekatan perundang-undangan (statute approach), pendekatan konseptual (conceptual approach), pendekatan perbandingan (comparative approach), dan pendekatan filosofis (philosophical approach) (Marzuki, 2005:92-95). Pendekatan perundang-undangan digunakan untuk meneliti, mendalami, dan menelaah berbagai peraturan perundangundangan yang mengatur model perencanaan pembangunan nasional. Pendekatan konseptual digunakan untuk mendalami model perencanaan pembangunan nasional yang ideal, apakah GBHN atau SPPN dengan RPJPN dan RPJMN yang saat ini ada. Lebih jauh, pendalaman perencanaan pembangunan model GBHN menggunakan pendekatan filosofis (philosophical approach) sebagai bentuk demokrasi konsensus yang sesuai dengan basis sosial masyarakat Indonesia.Sementara pendekatan perbandingan dilakukan dengan melihat beberapa negara yang mengatur directive principles atau GBHN dalam penyelenggaraan bernegaranya.

\section{PEMBAHASAN}

\section{A. Haluan Negara dan Sistem Pemerintahan Presidensil}

Haluan dalam Kamus Besar Bahasa Indonesia (KBBI) mengandung arti arah tujuan atau pedoman (http://badanbahasa.kemdikbud.go.id/kbbi/ index.php, diakses 24 Mei 2016). Bagi Jimly Asshiddiqie haluan negara sama dengan policy atau kebijakan (Asshiddiqie, 2010: 17). Haluan negara merupakan pedoman arah bagi penyelenggaraan negara. Haluan negara dapat berupa haluan politik baik di bidang ekonomi, kebudayaan, ataupun hukum. Dengan demikian istilah ini dapat dikaitkan dengan pengertian politik dalam arti luas, seperti tercermin dalam istilah politik ekonomi, politik kebudayaan, politik hukum, politik energi, politik pangan, dan sebagainya.

Istilah haluan negara sendiri dipergunakan dalam UUD NRI Tahun 1945 (Sebelum Perubahan) tepatnya Pasal 3 yang menyebut "MPR menetapkan UUD dan garis-garis besar daripada haluan negara” dan Penjelasannya “...DPR senantiasa dapat mengawasi tindakantindakan Presiden dan jika Dewan menganggap bahwa Presiden sungguh melanggar haluan negara yang telah ditetapkan oleh undang-undang dasar atau Majelis Permusyawaratan Rakyat..." (cetak tebal penulis). Dari kutipan tersebut, maka dapat diketahui bahwa haluan negara Indonesia dapat bersumber pada UUD NRI Tahun 1945 dan adapula yang ditetapkan oleh MPR.

Menurut Bagir Manan keberadaan GBHN dalam UUD 1945 Sebelum Perubahan tidak dapat dilepaskan dari soal kedaulatan rakyat (Manan dalam Harijanti, 2016: 18-19). Manan mengatakan:

"keinginan para pendiri negara dan penyusun UUD untuk menciptakan dan menyelenggarakan kedaulatan rakyat yang terarah dan terbimbing. Sebagai penjelmaan kedaulatan rakyat yang terarah dan terbimbing, diciptakan sistem garis-garis besar daripada haluan negara bukan sekedar wujud sistem kerja atas dasar perencanaan (planning system), tetapi sebagai sarana melaksanakan kedaulatan rakyat yang terarah dan terbimbing)"

Konteks kedaulatan menunjukkan bahwa ada keterkaitan antara Pasal 3 dengan Pasal 1 ayat (2) UUD 1945 Sebelum Perubahan.

Sementara itu, berdasarkan pengalaman UUD 1945 Sebelum Perubahan, Jimly menyebutkan haluan negara mencakup pengertian:

(1) Haluan negara yang tercantum dalam UUD 1945;

(2) Haluan negara yang tertuang dalam ketetapan-ketetapan MPR/S; 
(3) Haluan negara dalam pengertian program kerja yang tertuang dalam Ketetapan MPR tentang GBHN; dan

(4) Haluan negara yang tertuang dalam UU APBN. (Asshiddiqie, 2010: 18).

Lebih lanjut Jimly mengatakan bahwa segala bentuk peraturan perundangundangan yang mengikat umum juga berisi haluan, pedoman dan pegangan normatif yang harus dijadikan acuan dalam proses penyelenggaraan kekuasaan negara. Berdasarkan hal tersebut, maka Setelah Perubahan UUD 1945, haluan negara Indonesia meliputi UUD 1945, TAP MPR yang masih berlaku, UU APBN dan peraturan perundang-undangan lainnnya yang menunjukkan haluan dan pedoman dalam penyelenggaran negara.

Dengan dinormatifkannya berbagai macam haluan negara dalam bentuk hukum (peraturan perundang-undangan), maka dapat dikatakan bahwa haluan negara tersebut merupakan sebuah politik hukum (kebijakan hukum). Bagir Manan menyebutkan politik hukum ada yang bersifat tetap (permanen) dan ada yang temporer (Manan, Makalah 2003: 2-3). Politik hukum permanen atau tetap bagi Indonesia, antara lain: (i) ada satu kesatuan sistem hukum Indonesia; (ii) sistem hukum nasional dibangun berdasarkan dan untuk memperkokoh sendi-sendi Pancasila dan UUD 1945; (iii) tidak ada hukum yang memberikan hakhak istimewa pada warga negara tertentu berdasarkan suku, ras atau agama. Kalaupun ada perbedaan semata-mata didasarkan pada kepentingan nasional dalam rangka kesatuan dan persatuan bangsa; (iv) pembentukan hukum memperhatikan kemajemukan masyarakat; (v) hukum adat dan hukum tidak tertulis lainnya diakui sebagai subsistem nasional sepanjang nyata-nyata hidup dan dipertahankan dalam pergaulan masyarakat; (vi) pembentukan hukum sepenuhnya didasarkan pada partisipasi masyarakat; dan (vii) hukum dibentuk dan ditegakkan demi kesejahteraan umum (keadilan sosial bagi seluruh rakyat), terwujudnya masyarakat Indonesia yang demokratis dan mandiri serta terlaksananya negara berdasarkan atas hukum dan berkonstitusi. Politik hukum temporer adalah kebijaksanaan yang ditetapkan dari waktu kewaktu sesuai dengan kebutuhan. Seperti penentuan prioritas pembentukan peraturan perundang-undangan, penghapusan sisasisa peraturan perundang-undangan kolonial, pembaharuan peraturan perundang-undangan di bidang ekonomi, penyusunan peraturan perundangundangan yang menunjang pembangunan nasional dan sebagainya.

Adapun sistem UUD 1945 (Sebelum Perubahan) menghendaki suatu pola kebijaksanaan yang tersusun secara sistematik, spesifik dan terencana dari waktu ke waktu yang ditunjukkan adanya GBHN. Bagi Indonesia yang sedang membangun, politik hukum yang temporer lebih ditujukan pada pembaharuan hukum untuk mewujudkan suatu sistem hukum nasional dan berbagai aturan hukum yang dapat memenuhi kebutuhan Indonesia yang merdeka, berdaulat menuju masyarakat yang adil dan makmur. Karena itu politik hukum temporer ini seiring juga dengan kebijakan dalam bidang ekonomi, politik, sosial dan lain-lain.

Dari konsep haluan negara tersebut, diperoleh pembelajaran bahwa haluan negara Indonesia dapat termuat di berbagai macam peraturan perundang-undangan. Yang menarik UUD 1945 Sebelum Perubahan memang menghendaki adanya haluan negara sebagai pedoman bagi Indonesia yang sedang membangun. Bentuk hukum haluan negara sebagai wujud perencanaan pembangunan dengan model GBHN yang berisikan panduan program kerja yang bersifat konkrit dan dapat dievaluasi sesuai dengan kebutuhan perkembangan pembangunan.

Sementara itu, jika berbicara mengenai sistem pemerintahan, maka dalam konsep dasarnya, sistem pemerintahan dibedakan antara sistem pemerintahan parlementer 
dan sistem pemerintahan presidensil (Manan, 2006: 13-14). Sistem pemerintahan parlementer menampakkan berbagai ciri utama. Pertama, ada dua kelembagaan eksekutif, yaitu eksekutif yang menjalankan dan bertanggung jawab atas penyelenggaraan pemerintahan dan eksekutif yang tidak dapat diminta pertanggungjawaban atas penyelenggaraan pemerintahan. Eksekutif pertama biasanya disebut dengan kepala pemerintahan dan ada di tangan kabinet atau dewan menteri. Eksekutif kedua, adalah kepala negara, yaitu raja bagi kerajaan dan Presiden bagi republik. Pertanggungjawaban eksekutif kedua, dilaksanakan oleh eksekutif pertama. C.F. Strong menyebut real executive bagi eksekutif yang menjalankan dan bertanggungjawab atas jalannya pemerintahan dan nominal executive bagi eksekutif yang tidak dapat diminta pertanggungjawaban dalam menjalankan pemerintahan. Kedua, kabinet atau dewan menteri bertanggung jawab kepada badan perwakilan rakyat, sedangkan kepala negara tidak dapat diganggu gugat (can do no wrong). Maksud bertanggung jawab eksekutif adalah eksekutif tersebut dapat dijatuhkan dengan mosi tidak percaya oleh badan perwakilan. Adapun negara yang sering menjadi rujukan sistem pemerintahan parlementer adalah Inggris.

Adapun sistem pemerintahan presidensil hanya mengenal satu eksekutif. Fungsi kepala pemerintahan (chief executive) dan kepala negara (head of state) ada pada satu tangan dan tunggal (single executive). Pemegang kekuasaan eksekutif tunggal dalam sistem presidensil tidak bertanggung jawab kepada badan perwakilan rakyat, tetapi langsung kepada rakyat pemilih karena dipilih langsung atau dipilih melalui badan pemilih (electoral college). Karena itu masa jabatan Presiden biasanya tetap (fixed), dan hanya dapat dipertanggungjawabkan dalam jabatan melalui prosedur impeachment dengan alasan hukum. Adapun negara yang sering menjadi rujukan sistem pemerintahan presidensil adalah Amerika Serikat. Dalam praktiknya, muncul banyak varian dalam penyelenggaraan sistem pemerintahan, baik di parlementer maupun presidensil. Bahkan muncul varian campuran antara parlementer dan presidensil seperti di Perancis.

Dari uraian tersebut, inti dari sistem pemerintahan adalah berkaitan dengan tata cara pertanggungjawaban penyelenggaraan pemerintahan eksekutif dalam satu tatatanan negara demokrasi (Manan, 2005: 250). Berdasarkan korespondensi empirik yang dilakukan M. Adnan Yazar Zulfikar terhadap 194 konstitusi negaranegara di dunia yang diunggah Comparative Constitutions Project dari University of Texas, menunjukkan bahwa setiap negara yang menggunakan sistem pemerintahan parlementer mengatur pertanggungjawaban kepala pemerintahan kepada parlemen, sebaliknya kepala pemerintahan pada setiap negara yang menggunakan sistem presidensil tidak bertanggungjawab kepada badan legislatif (Zulfikar, 2016: 88).

Jika dilihat dari dua model sistem pemerintahan tersebut, maka sebagaimana telah diulas, sistem pemerintahan presidensil tidak menghendaki adanya pertanggungjawaban di tengah-tengah masa jabatan dalam urusan kebijakan. Hal tersebutlah yang membuat pola perencanaan pembangunan model GBHN berdasarkan UUD NRI Tahun 1945 Sebelum Perubahan ditinggalkan. Walau demikian, ada pelajaran yang dapat diambil dari penjabaran diatas, bahwa bagi Indonesia yang sedang membangun (development countries), perencanaan pembangunan yang terencana model GBHN layak untuk dipertimbangkan.

Melalui UU No. 25 Tahun 2004 tentang Sistem Perencanaan Pembangunan Nasional (SPPN) dan UU No. 17 Tahun 2007 tentang Perencanaan Pembangunan Jangka Panjang Nasional (RPJPN), sebenarnya pembangunan berencana telah diakomodir dalam peraturan perundangundangan. Walau demikian pe- 
laksanaannya dibentuk melalui Peraturan Presiden tentang Rencana Pembangunan Jangka Menengah Nasional (RPJMN). Dengan bentuk hukum Perpres, maka kedudukan Presiden sangat power full dalam menentukan perencanaan pembangunan jangka menengah 5 (lima) tahunan (RPJMN). Hal inilah yang di awal dikritik, karena perencanaan pembangunan menjadi Presiden sentris atau executive minded yang itu tidak sejalan dengan basis sosial rakyat Indonesia yang majemuk, beragam dengan sistem multi partai. Dengan bentuk hukum undang-undang untuk SPPN dan RPJPN serta lebih khusus peraturan presiden (perpres) untuk RPJMN, maka bentuk regulasinya lebih fleksible, dimana Presiden setiap saat dapat mengubahnya sesuai dengan kebutuhannya (Rohi, 2013: 87). Fleksibilitas regulasi tersebut membuat sistem perencanaan pembangunan sangat mudah berubah sesuai dengan keinginan pemimpin yang terpilih dan sedang memimpin.

\section{B. Sistem Presidensil yang Terpimpin Konstitusi dan Bentuk Hukum GBHN}

Sebagaimana sempat diutarakan, sistem presidensil yang saat ini dianut Indonesia merupakan pilihan terbaik sebagai bentuk penguatan derajat kedaulatan rakyat terutama berkaitan dengan pemilihan presiden yang langsung dilakukan oleh rakyat. Dengan demikian, presiden terpilih akan memiliki legitimasi yang tinggi serta memiliki ikatan (bonding) yang kuat dengan rakyatnya. Sebab itulah sistem presidensil ini masih layak dipertahankan.

Melalui pemilihan langsung, maka Calon Presiden dan Wakil Presiden dapat memberikan janji kampanye dalam memimpin pemerintahan dan menyelesaikan persoalan bangsa, sebagai bahan jualan kepada rakyat sehingga menjadi referensi rakyat dalam memilih. Sebagaimana sempat diutarakan, hal inilah yang menjadi persoalan, karena janji kampanye tersebut sering kali tidak memperhatikan pembangunan berkelanjutan dan terlalu Presiden sentris.

Ardilafiza menyebut sistem perencanaan pembangunan setelah perubahan UUD 1945 sebagai sistem perencanaan pembangunan yang pragmatis. Alasannya visi dan misi calon Presiden adalah satu-satunya dasar pilihan rakyat dalam pemilihan umum. Tidak ada batasan visi dan misi yang diperjanjikan pada pemilih, semuanya diserahkan pada mekanisme pasar. Tidak ada batasan yang mengarahkan atau membatasi visi dan misi calon Presiden, tidak juga konstitusi negara atau filosofis negara, apalagi keberlanjutan visi dan misi Presiden sebelumnya. Kebutuhan rakyat pemilih yang lebih bersifat emosional dan didasarkan pada kebutuhan sesaat menyebabkan pembangunan negara semakin tidak tentu arah karena tidak adanya skala prioritas yang harus dilakukan (Ardilafiza, 2016: 39-40).

Padahal perencanaan pembangunan yang berkelanjutan sebagaimana telah disinggung berkaitan erat dengan kedaulatan rakyat. Bagir Manan menjelaskan sebab mengapa pelaksanaan kedaulatan rakyat perlu bimbingan tidaklah semata-mata didasarkan atas pertimbangan efektivitas, efisiensi ataupun ketertiban dalam berdemokrasi, melainkan pula didasarkan pada pertimbangan bahwa rakyat belum memiliki dasar-dasar dan syarat-syarat untuk menjalankan demokrasi yang kompleks. Berdemokrasi membutuhkan kematangan (democratic maturity) (Manan dalam Harijanti, 2016: 19).

Sistem perencanaan pembangunan memiliki banyak manfaat. Misalnya Bagir Manan mengungkapkan beberapa manfaat dari sistem perencanaan pembangunan, yaitu: pertama, sebagai cara mewujudkan partisipasi demokratik dalam penyelenggaraan negara atau pemerintahan, terutama yang bertalian dengan pembangunan nasional; kedua, sebagai cara menjamin agar penyelenggaraan negara atau 
pemerintahan terutama pembangunan nasional dijalankan sesuai dengan kepentingan rakyat banyak; ketiga, sebagai cara menjaga efisiensi dan efektivitas penyelenggaraan negara dan pemerintahan cq pembangunan nasional, mengingat sumber-sumber (resources) dalam pembangunan terbatas (Manan, 2016: 2).

Banyak pihak yang menyebut model perencanaan pembangunan banyak dianut oleh negara-negara sosialis karena adanya dominasi negara dalam persoalan ekonomi dibandingkan negara-negara liberal yang lebih menyerahkan persoalan pembangunan ke mekanisme pasar. Hal tersebut memang menjadi diskursus mengenai hubungan antara peran negara dengan kondisi politik, ekonomi dan sosial. Namun demikian, menurut Bagir Manan, dalam perkembangan perbedaan tersebut tidak bersifat fundamental, karena di negara-negara baik dengan paham liberal maupun sosialis, perencanaan (planning) menjadi subsistem pengelolaan negara dan pemerintahan (Manan, 2016: 2).

Bertalian dengan dasar kedaulatan rakyat, kematangan berdemokrasi serta model demokrasi konsensus yang menjadi ciri demokrasi Indonesia, membutuhkan panduan pelaksanaannya. Karena itu, ide menghidupkan kembali GBHN sebagai panduan pembangunan menemui relevansinya. Pertanyaannya, bagaimana model penghidupan kembali GBHN yang masih sejalan dengan sistem presidensil yang hendak dianut?

Jimly Asshiddiqie dalam bukunya Konstitusi Ekonomi yang menyebutkan adanya gejala umum beberapa negara didunia memasukkan haluan negara dalam konstitusinya (Asshiddiqie, 2010: 100106). Konstitusi Irlandia sejak 1937 telah mencantumkan Directive Principles of State Policy (DPSP) yang berisikan panduan kebijakan ekonomi, mekanisme pasar bebas, intervensi negara dan lain-lain (Dalam Konstitusi Irlandia Perubahan 2015, bab tersebut berjudul Directive Principles of Social Policy). Sejak itu, banyak negara yang mengikuti pencantuman DPSP dalam konstitusinya, seperti Belgia, India, Filipina, Afrika Selatan dan lain-lain. Menurut Asshiddiqie, terjadi tren perumusan DPSP dalam konstitusi negara-negara di dunia saat ini yang berisikan konstitusi ekonomi sekaligus konstitusi sosial (Asshiddiqie, 2010: 107).

Yang menarik adalah model Filipina, mengingat Filipina menganut sistem presidensil yang artinya dapat menjadi contoh bagi Indonesia yang juga menganut sistem presidensil. Dalam Kontitusi Filipina 1987, ketentuan DPSP diatur dalam Pasal II dengan judul Declaration of Principles and State Policies, antara lain berisikan mengenai national economy and patrimony, persolan reformasi agraria dan kekayaan sumber daya alam, land reform perkotaan dan perumahan, perburuhan, dan lain-lain. Konstitusi Filipina sendiri membedakan secara tegas antara prinsipprinsip (principles) dan kebijakankebijakan (policies). Prinsip-prinsip dimaksudkan sebagai sebuah aturan yang mengikat (bindingrules) yang harus dipatuhi oleh pemerintah dalam melaksanakan berbagai tindakan, termasuk pembentukan aturan, sedangkan kebijakan-kebijakan merupakan petunjuk (guidelines) bagi orientas negara. Dalam praktiknya, perbedaan antara keduanya menjadi sumir karena tidak seluruh prinsip bersifat self-executor dan justru beberapa kebijakan menjadikan beberapa hak sebagai justiciablerights (Harijanti, 2016: 20).

Negara Brazil yang juga menerapkan sistem presidensil, memiliki ketentuan yang berisikan DPSP walaupun tidak diberikan judul DPSP. Dalam Konstitusi Brazil disebutkan beberapa bab penting misalnya mengenai prinsip-prinsip fundamental, hak-hak fundamental dan jaminannya, hak sosial, kewarganegaraan, hak politik dan lain-lain yang banyak berisikan prinsip-prinsip haluan negara (Konstitusi Brazil, dalam https://www.constituteproject.org/consti 
tution/Brazil_2015?lang=en, diakses 5 Agustus 2017). Hal sama terdapat di Korea Selatan yang juga menganut sistem presidensil, dalam konstitusinya mengatur mengenai hal-hal yang bersifat haluan negara berkaitan dengan hak dan kewajiban warga negara serta pembangunan dalam bidang ekonomi (Konstitusi Korea Selatan, https://www.constituteproject.org/consti tution/ Republic_of_Korea_1987? lang=en, diakses 5 Agutus 2017). Tiga negara tersebut, baik Filipina, Brazil dan Korea Selatan menjadi contoh negara yang menganut sistem presidensil yang juga mengatur prinsip-prinsip haluan negara dalam konstitusinya.

Tabel 1 Perbandingan Negara Yang Menerapkan Haluan Negara

\begin{tabular}{|c|c|c|}
\hline Negara & $\begin{array}{c}\text { Sistem } \\
\text { Pemerintahan } \\
\end{array}$ & Haluan Negara \\
\hline Irlandia & Sistem Parlementer & $\begin{array}{l}\text { Disebutkan secara tegas dalam Pasal } 45 \text { Konstitusi } \\
\text { Irlandia } 2015 \text { yang berjudul Directive Principles of } \\
\text { Social Policy. (sumber Konstitusi Irlandia 2015, } \\
\text { https://www.constituteproject.org/constitution/Ireland_2 } \\
\text { 015?lang=en, diakses 5 Agustus 2017). }\end{array}$ \\
\hline India & Sistem Parlementer & $\begin{array}{l}\text { Disebutkkan secara tegas dalam Bab IV Konstitusi India } \\
\text { dengan judul Directive Principles of State Policy, } \\
\text { (sumber Konstitusi } \\
\text { https://www.constituteproject.org/constitution/India_201 } \\
\text { 5?lang=en, diakses 5 Agustus 2017). }\end{array}$ \\
\hline Filipina & Sistem Presidensil & $\begin{array}{l}\text { Disebutkan secara tegas dalam Pasal II Konstitusi } \\
\text { Filipina } 1987 \text { dengan Declaration of Principles and State } \\
\text { Policies Principles, (sumber Konstitusi Filipina, } \\
\text { https://www.constituteproject.org/constitution/Philippin } \\
\text { es_1987?lang=en, diakses 5 Agustus, 2017). }\end{array}$ \\
\hline $\begin{array}{l}\text { Afrika } \\
\text { Selatan }\end{array}$ & $\begin{array}{l}\text { Sistem } \\
\text { pemerintahan } \\
\text { campuran }\end{array}$ & $\begin{array}{l}\text { Tidak disebutkan secara tegas dalam Konstitusi Afrika } \\
\text { Selatan, namun beberapa pengaturan di dalamnya } \\
\text { mengandung prinsip haluan negara (sumber Konstitusi } \\
\text { Afrika Selatan, } \\
\text { https://www.constituteproject.org/constitution/South_Af } \\
\text { rica_2012?lang=en, diakses } 5 \text { Agustus 2017). }\end{array}$ \\
\hline Brazil & Sistem Presidensil & $\begin{array}{l}\text { Tidak disebutkan secara tegas dalam Konstitusi Brazil, } \\
\text { namun beberapa pengaturan memperlihatkan prinsip- } \\
\text { prinsip haluan negara (sumber Konstitusi Brazil, } \\
\text { https://www.constituteproject.org/constitution/Brazil_20 } \\
\text { 15?lang=en, diakses } 5 \text { Agustus 2017). }\end{array}$ \\
\hline $\begin{array}{l}\text { Korea } \\
\text { Selatan }\end{array}$ & Sistem Presidensil & $\begin{array}{l}\text { Tidak disebutkan secara tegas dalam Konstitusi Korea } \\
\text { Selatan, namun beberapa pengaturan memperlihatkan } \\
\text { prinsip-prinsip haluan negara (sumber Konstitusi Korea } \\
\text { Selatan } \\
\text { https://www.constituteproject.org/constitution/Republic } \\
\text { _of_Korea_1987?lang= en, diakses 25 Agustus 2017) }\end{array}$ \\
\hline
\end{tabular}

Perbandingan beberapa negara tersebut menunjukkan telah terjadi tren perumusan haluan negara atau DPSP dalam konstitusi, baik secara langsung maupun tidak 
langsung, yang tidak menggantungkan pada sistem pemerintahan yang dianut. Dengan demikian, terjadi konvergensi yang menunjukkan perlunya haluan negara dalam pembangunan negara tersebut. Apabila dilihat hal tersebut tidak lain karena keterbutuhan negara-negara yang bersangkutan khususnya bagi negara berkembang.

Dengan melihat tren tersebut, maka menempatkan DPSP atau GBHN dalam konstitusi adalah suatu hal yang wajar. Karenanya, materi muatan konstitusi sebagaimana pendapat J.G. Steenbeek yang dikutip Sri Soemantri (Soemantri, 1987: 51), yakni (1) Jaminan hak-hak asasi manusia dan warga Negara; (2) Susunan ketatanegaraan yang bersifat fundamental; dan (3) Pembagian dan pembatasan tugas ketatanegaraan yang juga bersifat fundamental, sudah tidak cukup lagi. Selain 3 materi muatan yang prinsip tadi, maka materi muatan yang berisikan haluan pembangunan negara juga menjadi kebutuhan yang layak dimasukkan.

UUD NRI Tahun 1945 Setelah Perubahan, sebenarnya telah memuat beberapa ketentuan yang berkaitan dengan prinsip penyelenggaraan negara untuk mengurusi pendidikan dan kebudayaan (Bab XIII, Pasal 31 dan 32), serta perekonomian nasional dan kesejahteraan sosial (Bab XIV, Pasal 33 dan 34). Ketentuan tersebut sebenarnya dapat dikatakan sebagai sebuah haluan negara, walaupun tidak diberikan judul "GarisGaris Besar Haluan Negara". Namun, pada praktiknya sering kali dilanggar, misalnya dalam hal prioritas anggaran pendidikan sekurang-kurangnya dua puluh persen dari APBN dan APBD (Pasal 31 Ayat 4), penguasaan cabang-cabang produksi yang penting dan menguasai hajat hidup orang banyak dikuasai oleh negara (Pasal 33 Ayat 2 dan 3) yang ternyata diprivatisasi, maupun fakir miskin dan anak-anak yang terlantar dipelihara oleh negara (Pasal 34 Ayat 1). Atas dasar hal tersebut, semestinya ketentuan-ketentuan ini ditegaskan sebagai sebuah haluan negara disertai penyempurnaan-penyempurnaan sehingga dapat dijadikan pedoman pembangunan yang berkelanjutan serta dapat dilakukan penegakannya. Dari sinilah, cikal bakal GBHN yang termuat dalam Konstitusi Indonesia telah ada.

Selain itu, menempatkan GBHN dalam UUD NRI Tahun 1945 dianggap tepat jika dilihat dari basis sosial bangsa Indonesia. Sebagai negara kekeluargaan, maka sudah selayaknya pembangunan nasional tidak dirumuskan sendiri, tetapi harus dirumuskan bersama. Dengan demikian GBHN yang merupakan pedoman pembangunan berkelanjutan merupakan hasil konsensus bersama dari seluruh warga negaranya. Karenanya, selain menempatkan GBHN dalam UUD NRI Tahun 1945, patut pula dipikirkan agar MPR dapat kembali merepresentasikan seluruh kelompok kepentingan yang ada, mengingat saat ini MPR hanya merepresentasikan perwakilan politik dan daerah. Padahal, MPR yang dulu diidealkan para pendiri bangsa, menampung seluruh perwakilan baik politik, daerah maupun fungsional, sehingga ketika MPR melakukan permusyawaratan ia hendak menghadirkan negara persatuan yang dapat mengatasi paham perseorangan dan golongan, sebagai pantulan dari semangat kekeluargaan dari pluralitas kebangsaan Indonesia dengan mengakui adanya "kesederajatan/persamaan dalam perbedaan" (Latif, 2016: 148). Oleh karena itu perwakilan fungsional yang telah dihapuskan patut untuk diadakan kembali dengan model pengisian yang lebih jelas dan terukur.

Dengan menempatkan GBHN dalam UUD NRI 1945, maka status hukum GBHN akan sangat kuat. Sesuai dengan ajaran supremasi konstitusi yang dianut Indonesia, maka kedudukan GBHN-pun menjadi supreme. Sejalan dengan sistem presidensil yang dianut Indonesia, maka Calon Presiden dan Wakil Presiden dalam kampanye pemilihan umum, memberikan janji kampanye yang merupakan 
terjemahan dari GBHN yang tercantum dalam UUD NRI 1945. Dengan demikian, setelah terpilihpun, Presiden dan Wakil Presiden akan bekerja sesuai dengan janji kampanye yang selaras dengan GBHN, sehingga pembangunan berkelanjutanpun dapat dilaksanakan serta tidak ada lagi istilah pembangunan yang maju-mundur alias poco-poco. Atas dasar hal tersebut, maka sistem presidensil yang dianut adalah sistem presidensil yang terpimpin oleh konstitusi yang didalamnya termuat garis-garis besar haluan negara (GBHN).

GBHN yang termuat dalam konstitusi selain bersifat prinsip dan petunjuk, juga dapat berisikan rencana pembangunan jangka panjang nasional (misalnya 25 tahun atau 50 tahun). Dengan demikian, maka tujuan pembangunan nasional dalam jangka panjang secara berkelanjutan dapat lebih terencanakan. Karena itu, rencana pembangunan jangka panjang nasional (RPJPN) yang termuat dalam bentuk undang-undang dengan sendirinya dihapuskan. Sementara itu, berkaitan dengan rencana jangka pembangunan jangka menengah nasional (RPJMN) untuk jangka waktu 5 tahunan yang bersifat lebih teknis, merupakan manifestasi janji kampanye Presiden dan Wakil Presiden yang terpilih dalam pemilihan umum. Agar tidak melenceng dari GBHN yang termuat dalam konstitusi, maka RPJMN haruslah dibentuk dengan undang-undang. Artinya dengan persetujuan badan perwakilan rakyat, sehingga akan lebih mudah melakukan pengawasan terhadap pembentukan RPJMN tersebut.

Model RPJMN tersebut sebenarnya hampir mirip dengan model pluriannual plan yang diterapkan di Brazil. Berdasarkan penelitian Bilal Dewansyah, Brazil yang menganut sistem presidensil dan sistem bikameral, menerapkan pluriannual plan sebagai rencana multi tahun yang diajukan Presiden terpilih untuk jangka waktu 4 (empat) tahun. Selain sebagai pedoman perencanaan, pulriannual plan juga merupakan dokumen anggaran tahunan. Dengan melihat pihak yang mengajukan, maka sudah pasti rencana 4 tahunan tersebut didasarkan pada visi dan misi Presiden Brazil saat pemilu dan harus sesuai dengan indikatif anggaran (bahkan pada saat pemilu berlangsung, diadakan rapat yang dihadiri para perwakilan calon Presiden untuk menginformasikan kepada Kongres mengenai dokumen anggaran dan indikator anggaran yang masuk akal). Berdasarkan hal tersebut, menurut Bilal Dewansyah, pluriannual plan di Brazil seperti RPJMN di Indonesia karena berisikan janji kampanye Presiden, namun yang membedakannya pluriannual plan di Brazil harus dengan persetujuan Kongres Brazil, sementara RPJMN tidak membutuhkan persetujuan badan perwakilan rakyat karena dibentuk dengan peraturan presiden (Dewansyah, 2016:4749). Berdasarkan hal tersebut, maka ke depan, RPJMN yang dari awal disebut sebagai instrumen pembangunan yang President centris karena dibentuk dalam baju hukum peraturan presiden, diubah baju hukumnya dalam bentuk undangundang yang melibatkan perwakilan rakyat, sehingga lebih sesuai dengan GBHN yang termuat dalam UUD NRI Tahun 1945.

Dari uraian tersebut, meletakkan GBHN dalam UUD NRI Tahun 1945, dimana berisikan Directive Principles of State Policies dan rencana pembangunan jangka panjang, maka dengan sendirinya termuat politik hukum yang tetap dan temporer. Politik hukum yang temporer tersebut dapat berubah sesuai dengan perkembangan pembangunan. Akibat dari hal ini, maka proses perubahan UUD NRI Tahun 1945 menjadi terlembagakan sesuai dengan capaian kebijakan temporer tersebut. Hal ini yang mungkin saja dapat menimbulkan perdebatan baru, mengingat konstitusi sebuah negara selayaknya tidak sering diubah.

Dari segi keberlanjutan, konsep perencanaan pembangunan model GBHN lebih memiliki daya laku jangka panjang 
(Sajidin, 2016:99). Hal ini karena GBHN tidak akan berpengaruh keberlakukannya meskipun terjadi pergantian Presiden. Dengan demikian akan ada jaminan pemenuhan dan konsistensi pelaksanaan dokumen perencanaan yang telah dibuat dan tidak menyesuaikan diri dengan selera pemimpin yang baru.

\section{Implikasi Hukum Pelanggaran GBHN oleh Presiden dan Lembaga- Lembaga Negara Lainnya \\ Dengan menempatkan GBHN dalam} UUD NRI Tahun 1945, maka kedudukan hukum GBHN menjadi sangat kuat alias supreme. Atas dasar itu pelanggaran terhadap GBHN harus memiliki dampak atau implikasi yang jelas. Baik itu implikasi politik, sosial maupun hukum.

Secara politik dan sosial pelanggaran terhadap GBHN akan membuat Presiden dan lembaga-lembaga negara lainnya kehilangan legitimasinya, sehingga Presiden dan pemimpin lembaga-lembaga negara tersebut dianggap tidak mampu menjalankan GBHN sehingga tidak layak untuk dipilih kembali pada pemilihan berikutnya. Melalui mekanisme ini pula akan terbentuk budaya malu (shame culture) bagi pemimpin bangsa. Seperti Presiden Ke-3 Indonesia, Habibie yang menolak mencalonkan kembali menjadi Presiden karena Pidato Pertanggungjawabannya ditolak oleh MPR pada tahun 1999. Dalam konteks ini, implikasi politik dan sosial terhadap pelanggaran GBHN bersifat tidak mengikat dan hanya sebuah seruan moral saja.

MPR sebagai wujud perwakilan seluruh kelompok masyarakat yang ada dapat diberikan kewenangan memberikan penilaian atas kinerja Presiden maupun lembaga-lembaga negara lainnya dalam menjalankan GBHN. Untuk menghindari transaksi politik, maka penilaian tersebut harus dilakukan dengan menggunakan ukuran yang jelas dan secara terbuka. Penggunaan ukuran yang jelas untuk melihat rasionalitas anggota MPR dalam memberikan penilaian. Dilakukan secara terbuka untuk menutup transaksi politik yang sangat mungkin muncul.

Yang menjadi soal adalah implikasi hukum pelanggaran GBHN khususnya oleh Presiden. Apakah pelanggaran GBHN secara hukum dapat berimplikasi pada penjatuhan Presiden? Padahal sesuai dengan prinsip sistem presidensil, masa jabatan Presiden adalah tetap (fixed term) dalam rangka mendukung eksekutif yang kuat dan stabil (Strong, 1966: 364). Hal tersebut juga sejalan bahwa Presiden bukan bagian dari lembaga perwakilan sehingga Presiden tidak dapat dijatuhkan atau diberhentikan dari jabatannya oleh lembaga perwakilan. Begitu pula sebaliknya, Presiden pun tidak dapat membubarkan lembaga perwakilan. Dalam sistem presidensil, Presiden hanya dapat diberhentikan pada masa jabatan karena alasan hukum dalam proses impeachment (Manan, 2006: 37).

Berpedoman pada hal tersebut, maka kurang tepat kiranya jika pelanggaran GBHN oleh Presiden dipergunakan sebagai alat untuk melakukan pemberhentian karena akan merusak bangunan sistem presidensil itu sendiri. Tetapi tanpa adanya implikasi hukum, maka wibawa GBHN yang telah dimasukkan kedalam konstitusi menjadi hilang, karena pelanggaran terhadap GBHN yang hanya bersifat moral dan tidak mengikat.

Untuk itu, dalam konstruksi sistem pemerintahan presidensil, ada dua mekanisme sebagai bentuk implikasi pelanggaran GBHN yakni pranata hak budget parlemen dan melalui pengadilan. Pertama melalaui pranata hak budget parlemen, yakni instrumen parlemen dalam pemberian persetujuan RAPBN yang diajukan Presiden yang menurut Bagir Manan adalah salah satu pengawasan yang efektif terhadap Pemerintah. Bagir Manan dalam makalah Himpunan Tulisan Ilmiah Tentang Sistem Hukum Di Indonesia, menyebutkan hak budget lembaga legislatif memiliki 
kedudukan yang strategis. Hal tersebut disandarkan pada pendapat Hamilton yang menyebut cabang legislatif kuat karena menguasai pundi-pundi uang (purse). Yang dimaksudkan pundi-pundi uang adalah hak anggaran (hak budget). Sebagai pemegang hak anggaran, cabang legislatif menentukan anggaran belanja negara. Badan legislatif menentukan aloasi anggaran tahunan, bahkan dapat menolak rencana anggaran yang diajukan pemerintah. Selain itu, Hamilton juga mengatakan kalau cabang eksekutif juga kuat karena menguasai pedang (sword). Yang dimaksudkan dengan pedang adalah adanya apatur pemerintah seperti tentara, polisi, jaksa dan lain-lain aparatur administrasi negara sebagai pelaksana yang menjalankan dan menegakkan kekuasaannya. Sementara cabang kekuasaan yang paling lemah menurut Hamilton adalah kekuasaan kehakiman (yudikatif) karena tidak memiliki pundipundi uang maupun pedang (aparatur) yang akan menopang pelaksanaannya. Bahkan untuk melaksanakan putusannya, kekuasaan kehakiman tergantung pada pemerintah (eksekutif), misalnya jaksa sebagai eksekutor putusan hakim (untuk perkara pidana) (Manan, 200-2001: 2). Karena kuatnya kewenangan badan perwakilan rakyat dalam penentuan anggaran, Kongres Amerika dapat menolak memberikan persetujuan terhadap proposal anggaran yang diajukan pemerintah. Akibat penolakan Kongres tersebut, pemerintahan Amerika terancam ditutup (government shutdown) karena penyelenggaraan pemerintahan tidak mungkin dijalankan tanpa adanya anggaran. Berdasarkan laporan Congressional Research Service, pemerintahan Amerika mengalami penutupan pada tahun 1996 selama 21 hari dari 16 Desember 1995 sampai dengan 6 Januari 1996, dan pada tahun 2013 selama 16 hari dari 1 Oktober 2013 sampai dengan 16 Oktober 2013 (Nagel dan Murray, 2015).
Walaupun hak budget parlemen khususnya DPR tidak sekuat hak budget Kongres Amerika, karena dalam konstitusi Indonesia, tidak disetujuinya RAPBN tidak membuat government shutdown, melainkan pemerintah menggunakan APBN tahun sebelumnya (Susanto, 2016: 71-73), namun hak anggaran tersebut tetap dapat dijadikan sebagai alat untuk melakukan kontrol terhadap pelaksanaan GBHN. Apabila Presiden dan Wakil Presiden, serta lembaga-lembaga negara lainnya melakukan pelanggaran terhadap GBHN, maka MPR dapat memerintahkan DPR (dimana sebagian anggota MPR adalah anggota DPR), untuk menolak RAPBN yang diajukan Presiden. Melalui mekanisme ini, Presiden dan Wakil Presiden serta lembaga-lembaga negara lainnya dipaksa untuk membuat rencana program pembangunan dalam RAPBN yang sesuai dengan GBHN, jika tidak sesuai maka proposal anggaran tersebut dapat ditolak.

Pranata kedua yang dapat dilakukan adalah melalui pengadilan. Kalau menggunakan perbandingan negara-negara yang telah memuat materi GBHN dalam konstitusinya, maka prinsip haluan negara sebenarnya tidak untuk dibawa ke pengadilan (Asshiddiqie, 2010: 107-108). Ketentuan yang directive dalam haluan negara tersebut dimaksud hanya untuk memberikan pedoman moral dan politik penyelenggara negara untuk menjabarkannya dalam kebijakan yang bersifat operasional. Bahkan dalam Konstitusi India Pasal 36 disebutkan "No questions shall be raised in any court as to whether provisions contained in this Part are implemented or not". Tiada permasalahan yang dapat diajukan ke pengadilan apakah ketentuan dalam bagian ini dapat dilaksanakan atau tidak. Dalam ketentuan lebih lanjut, disebutkan bahwa negara harus memobilisasikan sumber daya yang diperlukan untuk melaksanakan prinsipprinsip dan haluan negara.

Namun dalam perkembangannya, Mahkamah Agung India mengembangkan 
penafsiran yang berhasil menjembatani antara prinsip-prinsip hak asasi manusia dengan prinsip-prinsip haluan negara/DPSP. Menurut MA India, directive principles dapat saja ditegakkan di pengadilan, tetapi penegakannya itu bukanlah karena kekuatan directive principles itu sendiri, melainkan hanya apabila directive principles itu berisi hak asasi manusia.

Selain itu, ada juga Putusan MK Afrika Selatan dalam kasus Irene Grootboom and others yang dianggap sebagai landmark decision. Kasus ini berkaitan dengan fakta adanya 900 orang (anak dan dewasa) yang hidup dalam lingkungan yang sangat menjijikkan. Mereka kemudian pindah ke sebuah gedung kosong milik perorangan yang berada di seberang jalan tempat semula mereka tinggal. Suatu hari, pemilik gedung hendak meruntuhkan bangunan. Dengan dukungan dewan kota, pemilik gedung mendapatkan surat perintah pengadilan untuk meruntuhkan gedung. Mereka tidak mungkin kembali ke lokasi lama karena di lokasi tersebut telah ditempati orang lain. Salah satu penghuni gedung, yaitu Irene Grootboom membawa perkara ini Mahkamah Konstitusi Afrika Selatan dengan asalan adanya jaminan perumahan yang layak dalam konstitusi. Pada sidang awal, pihak pemerintah memberikan beberapa tawaran, yaitu akses tanah, bahan bangunan serta akses beberapa kebutuhan atau pelauanan dasar. Penghuni menerima tawaran tersebut, namun ternyata pemerintah tidak memenuhi janjinya. Oleh karena itu, Irene Grootboom mengajukan permohonan ke MK untuk mengeluarkan 'perintah' yang memaksa Pemerintah memenuhi janjinya. Dalam putusannya MK Afrika Selatan mengeluarkan dua "declaratory order", yakni: 'a specific order adderssing the breach by the goverment of its agreement with wallacedene community that required its reinstantement', dan 'a general order declaring (1) that section 26 (2) requires the state to devise and implement a program to progressively implement the right to acces to housing, (2) that the program must include measures that provide for people crisis situations, and (3) that the program cureently in place falls short of consntitutional requirements', (Harijanti, 2011, dari http://pustaka.unpad.ac.id/wp-content/ uploads/2016/04/Artikel-14.pdf, diakses 25 Mei 2016). Putusan MK Afrika Selatan memerintahkan negara untuk memenuhi kewajiban menyediakan perumahan yang layak bagi warganya yang sejalan dengan haluan negara yang terdapat dalam Konstitusi Afrika Selatan. Sebelum putusan tersebut keluar, secara tradisional hak-hak ekonomi, sosial dan budaya dianggap tidak dapat ditegakkan di pengadilan dan bersifat non-enforceable, sementara yang dapat ditegakkan adalah hak sipil dan politik (Asshiddiqie, 2010: 108-109). Dengan adanya putusan MA India dan MK Afrika Selatan, maka hak ekonomi, sosial dan budaya harus juga dapat ditegakkan di pengadilan.

Tabel 2 Perbandingan Penegakan Hukum Haluan Negara

\begin{tabular}{|c|c|}
\hline $\begin{array}{c}\text { Negara dengan Haluan Negara } \\
\text { dalam Konstitusinya }\end{array}$ & Penegakan Hukum Haluan Negara \\
\hline India & $\begin{array}{l}\text { Dalam Konstitusi India ditegaskan jika Haluan } \\
\text { Negara tidak dapat ditegakkan melalui pengadilan, } \\
\text { namun Mahkamah Agung India berpendapat bahwa } \\
\text { Haluan Negara dapat saja ditegakkan di pengadilan, } \\
\text { tetapi penegakannya bukanlah karena kekuatan dari } \\
\text { Haluan Negara tersebut, melainkan hanya apabila } \\
\text { Haluan Negara berisikan hak asasi manusia. } \\
\text { Dengan demikian, yang ditegakkan adalah konteks }\end{array}$ \\
\hline
\end{tabular}




\begin{tabular}{|l|l|}
\hline Afrika Selatan & hak asasi manusia itu sendiri. \\
\hline & Afrika Selatan pada awalnya hanya mengenal \\
penegakan hukum di pengadilan hanya untuk hak \\
asasi manusia bidang sipil dan politik, sementara \\
hak ekonomi, sosial dan budaya tidak dapat \\
ditegakkan di pengadilan. Dalam perkara Irene \\
Grootboom and others, Mahkamah Konstitusi \\
Afrika Selatan memutuskan hak perumahan yang \\
layak yang merupakan bagian dari hak ekonomi \\
harus dipenuhi karena merupakan haluan negara. \\
Dengan demikian, haluan negara yang bertalian \\
dengan hak asasi manusia dapat ditegakkan di \\
pengadilan.
\end{tabular}

Dengan demikian, jika sebelumnya hak asasi manusia di bidang sipil dan politik saja yang dapat ditegakkan dipengadilan (enforceable), sementara hak asasi manusia dalam bidang ekonomi, sosial dan budaya tidak dapat ditegakkan (non enforceable atau non justiciable), maka melalui putusan pengadilan tersebut, hak asasi manusia di bidang ekonomi, sosial dan budaya dapat ditegakkan. Adapun hal itu dimasukkan ke dalam haluan negara yang diatur dalam konstitusi. Karena itu, pelanggaran terhadap GBHN khususnya yang berkaitan dengan hak asasi manusia, sangat mungkin ditegakkan melalui pengadilan.

Hal tersebut menjadi pelajaran bagi bangsa Indonesia, ke depan jika GBHN telah dimuat dalam UUD NRI Tahun 1945, maka Mahkamah Konstitusi sangat mungkin menerima gugatan judicial review terhadap undang-undang yang tidak sejalan dengan GBHN. Salah satunya UU APBN dimana anggaran negara tidak diarahkan untuk memenuhi haluan negara tersebut, atau juga peraturan perundangundangan lainnya yang tidak sejalan dengan GBHN. Selain itu juga kalau constitutional complaint diakomodir sebagai salah satu kewenangan MK, maka hal tersebut dapat pula dipergunakan sebagai pranata mengecek pelanggaran GBHN oleh Presiden dan lembagalembaga negara lainnya. Constitutional complaint adalah salah satu upaya hukum untuk menjamin tidak dilanggarnya hak konstitusional warga negara oleh seluruh kebijakan pemerintah maupun putusan peradilan. Di berbagai negara, constitutional complaint menjadi bagian dari kewenangan Mahkamah Konstitusi (Ayuni, 2010).

\section{KESIMPULAN}

Menghidupkan kembali GBHN dalam ketatanegaraan Indonesia tidak selalu bertentangan dengan sistem pemerintahan presidensil yang dianut. Salah satu modelnya adalah dengan meletakkan GBHN sebagai Directive Principles of State Policies di dalam UUD NRI Tahun 1945 dan tidak menjadikannya sebagai alat pertanggungjawaban bagi Presiden dan Wakil Presiden. GBHN inipun dapat menjadi politik hukum yang tetap yang tidak perlu diubah dan juga menjadi politik hukum temporer (tidak tetap) khususnya berkaitan dengan pembangunan jangka panjang. Dengan demikian dimungkinkan adanya pelembagaan Perubahan UUD NRI Tahun 1945 setelah GBHN jangka panjang tersebut terlaksana misalnya dalam 25 (dua puluh lima) atau 50 (lima puluh) tahun sekali. Model GBHN dalam UUD NRI Tahun 1945 tersebut dapat diakomodir dengan cara melakukan Perubahan UUD NRI Tahun 1945.

Adapun implikasi pelanggaran GBHN oleh Presiden dapat berupa sanksi sosial, politik dan hukum. Implikasi sosial dan politik dapat dikeluarkan oleh MPR, sehingga Presiden dianggap tidak cakap dan tidak pantas lagi menduduki jabatannya pada pemilihan berikutnya. 


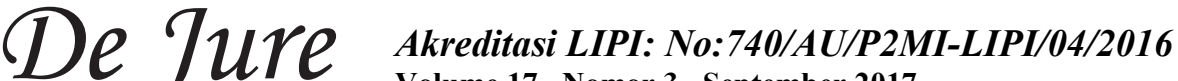

Volume 17, Nomor 3, September 2017

Implikasi sosial dan politik ini masih bersifat moral dan himbauan saja. Sementara itu implikasi hukum yang bersifat mengikat, tidak dapat membuat dijatuhkannya Presiden karena tidak sejalan dengan sistem presidensil yang dianut. Karena itu, implikasi hukum pelanggaran GBHN dapat dilakukan dalam dua bentuk, pertama MPR memerintahkan DPR menggunakan hak budget yang dimiliki untuk menolak proposal RAPBN. Dengan demikian Presiden dan Lembaga Negara Lainnya dipaksa membentuk rencana program dan anggaran yang sesuai dengan GBHN. Kedua, melalui mekanisme pengadilan. Melalui Mahkamah Konstitusi, sangat mungkin menerima judicial review dan constitutional complaint jika ada kebijakan negara yang tidak sesuai dengan GBHN yang termuat dalam UUD NRI Tahun 1945.

\section{SARAN}

Wacana menghidupkan kembali GBHN dalam sistem presidensil di Indonesia adalah sangat mungkin dan wajar sebagai negara berkembang yang membutuhkan pedoman perencanaan pembangunan. Untuk itu diperlukan perubahan UUD NRI Tahun 1945 yang mengakomodir penghidupan kembali GBHN dengan cara memasukkannya di dalam UUD NRI Tahun 1945 secara langsung yang didalamnya termuat kebijakan perencanaan pembangunan yang bersifat prinsip dan pedoman untuk jangka panjang. Sementara itu, visi dan misi serta janji kampanye Presiden dan Wakil Presiden dimuat dalam perencanaan pembangunan jangka menengah yang dibentuk dengan undang-undang untuk mengurangi President Centris. Langkah yang dapat dilakukan dalam mengakomodir hal ini adalah dengan mendorong MPR sebagai lembaga yang memiliki kewenangan untuk melakukan Perubahan UUD NRI Tahun 1945 untuk melakukan Perubahan UUD NRI Tahun 1945 yang mengakomodir penghidupan kembali GBHN secara langsung di dalam batang tubuh UUD NRI tahun 1945. 


\section{DAFTAR KEPUSTAKAAN}

\section{Buku, Jurnal dan Makalah}

Ardilafiza, Reformulasi Sistem Perencanaan Pembangunan Nasional Model Garis-Garis Besar Haluan Negara Dalam Ketatanegaraan Indonesia, Jurnal Majelis, MPR RI, Edisi 4 Tahun 2016.

Asshiddiqie, Jimly, Pokok-Pokok Hukum Tata Negara Indonesia Paska Reformasi, Buana Ilmu Populer, Jakarta, 2008.

--------, Konstitusi Ekonomi, Kompas Media Nusantara, Jakarta, 2010.

Ayuni, Qurrota, Menggagas Constitutional Complaint di Indonesia, Jurnal Konstitusi, No. 1, April 2010.

Dewansyah, Bilal, Menempatkan GBHN Dalam Setting Sistem Presidensial Indonesia: Alternatif dan Konsekuensinya, Jurnal Majelis, MPR RI, Edisi 4 Tahun 2016.

Harijanti, Susi Dwi, Merumuskan Ulang Garis-Garis Besar Haluan Negara, Jurnal Majelis, MPR RI, Edisi 4 Tahun 2016.

Isra, Saldi, Wacana Menghidupkan $G B H N$, Jurnal Majelis, MPR RI, Edisi 4 Tahun 2016.

Istanto, F. Sugeng, Penelitian Hukum, CV. Ganda, Yogyakarta, 2007.

Latif, Yudi, Pembukaan Undang-Undang Dasar Sebagai Cita Negara dan Cita Hukum, Jurnal Ketatanegaraan, Lembaga Pengkajian MPR RI, Vol. 001, Desember 2016.

Manan, Bagir, Politik PerundangUndangan, Makalah, Jakarta, November 1993.

--------, Himpunan Tulisan Ilmiah Tentang Sistem Hukum Di Indonesia, Bandung, dihimpun oleh Mahasiswa Program Doktor Ilmu hukum Program Pascasarjana Universitas Padjadjaran Angkatan 2000/2001, 2000.

-------, DPR, DPD, dan MPR dalam UUD 1945 Baru, FH UII Press, Yogyakarta, 2003.
------, Menyongsong Fajar Otonomi Daerah, Pusat Studi Hukum FH UII, Yogyakarta, 2005.

------, Lembaga Kepresidenan, FH UII Pres, Yogyakarta, 2006.

------, Mewujudkan Masyarakat Madani Dalam Negara Kesatuan Republik Indonesia, Makalah, 2016.

Marzuki, Peter Mahmud, Penelitian Hukum, Kencana Prenada Media Group, Jakarta, 2005.

Rohi, Sofia L., Implikasi Amandemen Undang-Undang Dasar 1945 terhadap Sistem Perencanaan Pembangunan Nasional, Jurnal Politika, Vol. 4. No. 1. April 2013.

Sadono, Bambang, Reformulasi GBHN, Penguatan MPR, dan Penataan DPD, Jurnal Majelis, MPR RI, Edisi 4 Tahun 2016.

Sajidin, Syahrul, Pencapaian SDGS (Sustainable Development Goals) Dengan Perencanaan Model GBHN, Jurnal Majelis, MPR RI, Edisi 4 Tahun 2016.

Soekanto, Soerjono, Pengantar Penelitian Hukum, UI Press, Jakarta, 2007.

Soemantri, Sri, Prosedur dan Sistem Perubahan Konstitusi, Alumni, Bandung, 1987.

Strong, C.F., Modern Political Constitutions, Sidgwick and Jackson, 1966.

Susanto, Mei, Eksistensi Hak Budget DPR Dalam Sistem Ketatanegaraan Indonesia, Padjadjaran Jurnal Ilmu Hukum (PJIH), Vol. 3 No. 1, Tahun 2016.

Zulfikar, M. Adnan Yazar, Inhibisi Politik: MPR Sebagai Lembaga Tertinggi Negara, Jurnal Majelis, MPR RI, Edisi 3 Tahun 2016.

\section{Peraturan Perundang-Undangan}

UUD 1945 Sebelum Perubahan

UUD 1945 Setelah Perubahan

Republik Indonesia, UU No. 25 Tahun 2004 Tentang Sistem Perencanaan Pembangunan Nasional, LN Tahun 2004 No. 104, TLN No. 4421. 


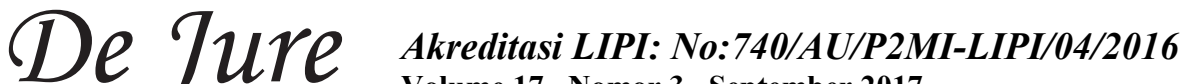 \\ Volume 17, Nomor 3, September 2017}

Republik Indonesia, UU No. 17 Tahun 2007 Tentang Rencana Pembangunan Jangka Panjang Nasional, LN Tahun 2007 No. 33, TLN No. 4700.

\section{Koran dan Internet}

Jared N. Nagel dan Justin Murray, Past Government Shutdowns: Key Resources, Congressional Research Service, 29 September 2015. Diunduh dari https://www.fas.org/sgp/crs/misc/ R41759.pdf, diakses 8 Juni 2016.

Konstitusi Brazil, https://www. constituteproject.org/constitution/Brazil 2015?lang=en, diakses 5 Agustus 2017).

Konstitusi Filipina, https://www. constituteproject.org/constitution/Philip pines_1987?lang=en, diakses 5 Agustus, 2017.

Konstitusi India, https://www. constituteproject.org/constitution/India 2015?lang=en, diakses 5 Agustus 2017.

Konstitusi Irlandia 2015, https://www. constituteproject.org/constitution/Irelan d 2015?lang=en, diakses 5 Agustus 2017.

Konstitusi Korea Selatan 1987, https://www.constituteproject.org/const itution/Republic_of_Korea_1987?lang $=$ en, diakses 25 Agustus 2017).

Saldi Isra di Harian Kompas 12 Januari 2016, Wacana Menghidupkan GBHN, dapat diakses di http://nasional.kompas.com/read/2016/ 01/12/15320071/Wacana.Menghidupka n.GBHN?page=all,diakses, 6 Juni 2016.

Susi Dwi Hajanti, Perumahan Yang Layak Sebagai Hak Asasi Manusia, Majalah inforum, Edisi 3 Tahun 2011. Diunduh dari http://pustaka.unpad.ac.id/wpcontent/uploads/2016/04/Artikel14.pdf, diakses 25 Mei 2016.

Yudi Latif, Basis Sosial GBHN, Harian Kompas 12 Februari 2016. http://print.kompas.com/baca/2016/02/ 12/Basis-Sosial-GBHN, diakses 25 Mei 2016. http://badanbahasa.kemdikbud.go.id/kbbi/i ndex.php, diakses 24 Mei 2016. http://nasional.kompas.com/read/2016/01/ 10/16053561/Kritik.Demokrasi.Indone sia.Megawati.Sebut.seperti.Pocopoco, diakses 25 Mei 2016. 